\title{
Expression of candidate genes related to metabolism, immunity and cellular stress during massive mortality in the American oyster Crassostrea virginica larvae in relation to biochemical and physiological parameters
}

\author{
GENARD Bertrand ${ }^{1}$, MORAGA Dario ${ }^{2}$, PERNET Fabrice ${ }^{3}$, DAVID Élise ${ }^{2,4}$, \\ BOUDRY Pierre ${ }^{5}$ and TREMBLAY Réjean ${ }^{{ }^{*}}$
}

1 Institut des sciences de la mer, Université du Québec à Rimouski, 310, allée des Ursulines, Rimouski, Québec, G5L 3A1, Canada

${ }^{2}$ Laboratoire des Sciences de l'Environnement Marin (LEMAR), Institut Universitaire Européen de la Mer, Université de Bretagne Occidentale, Plouzané, France

${ }^{3}$ Ifremer, Laboratoire Environnement Ressources en Languedoc-Roussillon, Bd Jean Monnet, Sète, France

${ }^{4}$ Laboratoire Ecologie Ecotoxicologie, UPRES-EA2069 Unité de Recherche " Vigne et Vins de Champagne : Stress et Environnement " (URVVC), Université de Reims Champagne-Ardenne, BP 1039, 51687 Reims Cedex 02, France

${ }^{5}$ Ifremer, Laboratoire de Physiologie des Invertébrés, Technopole de Brest-Iroise BP 7029280 , Plouzané, France

* Corresponding author : rejean tremblay@uqar.qc.ca

\begin{abstract}
:
Quantification of mRNA of genes related to metabolism, immunity and cellular stress was examined in relation to a massive mortality event during the culture of American oyster larvae, Crassostrea virginica which was probably, in regard to previous microbiological analysis, induced by vibrio infection. To document molecular changes associated with the mortality event, mRNA levels were compared to biochemical and physiological data, previously described in a companion paper. Among the 18 genes studied, comparatively to the antibiotic control, 10 showed a lower relative gene expression when the massive mortality occurred. Six of them are presumed to be related to metabolism, corroborating the metabolic depression associated with the mortality event suggested by biochemical and physiological analyses. Relationships between the regulation of antioxidant enzyme activities, lipid peroxidation, and the mRNA abundance of genes linked to oxidative stress, cytoprotection, and immune response are also discussed. Finally, we observed an increase in the transcript abundance of two genes involved in apoptosis and cell regulation simultaneously with mortality, suggesting that these processes might be linked.
\end{abstract}

Keywords: Crassostrea virginica, massive mortality, relative gene expression, metabolism, immunity, cellular stress, larvae. 


\section{Introduction}

Massive mortality of bivalve larvae has often been associated with a low quality of water or of micro algae provided as food for aquaculture production, promoting the proliferation of opportunistic pathogenic microorganisms (Olafsen 2001; Paillard et al. 2004). Many studies have been dedicated to the identification and characterization of pathogenic microorganisms to such mortalities but, to our knowledge, few physiological or molecular studies have yet been carried out to study larvae during such mortality events. This is indeed related to the technical difficulties to study such rapid phenomenon on very small organisms. In addition to biochemical and physiological approach (Tukinov et al. 2010), recently developed genomic tools can now be used to better document larval responses. In the last decade, cDNA collections and Expressed Sequence Tags (EST) have been developed for several bivalve species, and they account for the large number of RNA sequences available in public databases (Jenny et al. 2007; Quilang et al. 2007; Tanguy et al. 2008; Fleury et al. 2009; Zapata et al. 2009; Collin et al. 2010; Sussarellu et al. 2010). Such an increasing number of EST databases provide the opportunity to characterize bivalve mortality events and infections (Huvet et al. 2004; Samain et al. 2007; Fleury et al. 2009; Travers et al. 2010) In the American oyster, EST collections are being used to identify genes with putative functions in the cellular and biochemical processes implicated in the resistance to Perkinsus marinus (Tanguy et al. 2004; Wang et al. 2010).

To date, the majority of genomic approaches have been carried out on adult bivalves and little is known about gene regulation at larval stage. Jenny et al. (2002) produced two EST collections from embryos and haemocytes of the American oyster to identify genes that are potentially related to immune and stress response. More recently, Tirape et al. (2007) studied the expression of immune-related genes during ontogeny and bacterial challenge in C. gigas.

In this context, we selected 18 candidate genes, presumed to be involved in metabolism (energy production, protein synthesis, and lipid remodelling), immunity (pathogen recognition, proteinase, apoptosis, and inflammatory response) and cellular stress (antioxidant defences, xenobiotic detoxification and cytoprotection). Relative expression of these 18 genes was studied by quantification of mRNA using real time PCR, during a mortality event in larvae of the American oyster C. virginica and compared with an antibiotic-treated control that showed no significant mortality. Results are discussed in the light of biochemical and physiological data reported in a companion paper (Genard et al. 2011).

\section{Materials and methods}

\subsection{Experimental design and physiological characterization of a bacterial mortality event}

Details about the rearing procedure and experimental design are presented in Genard et al. (2011). Briefly, this work was done at the hatchery of the Coastal Zone Research Institute (CRZI, Shippagan, New Brunswick, Canada) during winter 2006. After fertilization, larvae were reared in a $415 \mathrm{~L}$ Xactic@ tank in filtered seawater. Larvae were fed with a mixture of three microalga species Isochrysis sp. (T-ISO), Pavlova lutheri (MONO), and Chaetoceros muelleri (CHGRA). Two days after fertilization, D-larvae were collected, enumerated and split equally into two experimental treatments. Larvae were cultivated in triplicate with or without antibiotic (chloramphenicol at $4 \mathrm{mg} \mathrm{L}^{-1}$; Fluka, Mississauga, ON). Larval samples (100 000 larvae per sample) were collected at 6,13 , and $20 \mathrm{dpf}$ (days post fertilization).

Mortality event occurred 20 days after fertilization in untreated tanks (see Genard et al. 2011 for further details). Mortality was associated with (1) strong changes in the bacterial community structure, (2) a progressive decrease in feeding activity, (3) higher levels of some lipid classes (free fatty acids, diglycerides, and acetone mobile phospholipids), (4) lower levels of phospholipids and protein, (5) higher contents of non-methylene interrupted dienoic fatty acids 
(22:2 NMI), (6) a decrease in energy metabolism activity (citrate synthase and cytochrome oxidase activities), (7) a higher oxidative stress (lipid peroxidation level), and (8) an activation of antioxidant defences before mortality (glutathione peroxidase and superoxide dismutase).

\subsection{Real-time PCR}

Total RNA was extracted for each replicate (between 2 and 3 depending on larval availability) using TRIzol ${ }^{\mathrm{TM}}$ Reagent (Invitrogen, Carlsbad, CA) according to the manufacturer's protocol. RNA was resuspended in RNase-free water and concentrations were determined by OD260 measurements. Ten micrograms of total RNA extracted from each developmental stage were reverse transcribed using the oligo(dT) anchor primer and Moloney murine leukaemia virus (MMLV) reverse transcriptase (Promega). Real-time PCR was performed with $5 \mu \mathrm{L}$ cDNA (1/20 dilution) in a total volume of $25 \mu \mathrm{L}$, using a 7300 Real-Time PCR System (Applied Biosystems, Foster City, CA). The concentrations of the reaction components were $1 \times$ Absolute QPCR SYBR Green ROX Mix (ABgene, Epsom, UK) and $70 \mathrm{nM}$ of each primer. Reactions began with the activation of Thermo-Start DNA polymerase at $95^{\circ} \mathrm{C}$ for $15 \mathrm{~min}$ followed by amplification of the target cDNA (50 cycles of denaturation at $95^{\circ} \mathrm{C}$ for $30 \mathrm{~s}$, annealing and extension at $60^{\circ} \mathrm{C}$ for 1 $\mathrm{min})$, and melting curve analysis was performed with continuous fluorescence acquisition $\left(95^{\circ} \mathrm{C}\right.$ to $70^{\circ} \mathrm{C}$ at a temperature transition rate of $0.5^{\circ} \mathrm{C}$ every $10 \mathrm{~s}$ ) to determine the amplification specificity. Each run included a negative control (non reverse-transcribed total RNA) and blank controls (water) for each primer pair.

The relative level of target gene expression was based on a comparative method (Livak and Schmittgen, 2001; Pfaffl, 2001). The threshold value (Ct) was determined for each target as the number of cycles at which the fluorescence curve entered exponential phase. The relative quantification value of a sample is expressed as $2^{-\Delta \Delta \mathrm{Ct}}$, where $\Delta \Delta \mathrm{Ct}=\Delta \mathrm{Ct}$ (target sample) $-\Delta \mathrm{Ct}$ (reference sample) and $\Delta \mathrm{Ct}=\mathrm{Ct}$ (target gene)-Ct (housekeeping gene). Three genes coding for a ribosomal protein subunit were selected as putative housekeeping genes. All of these reference genes were amplified at all stages and in the two treatments. Ribosomal $18 \mathrm{~s}$ was found to have the lowest variation during the experiment and was then chosen as the housekeeping gene for the rest of the analyses. Larvae treated with antibiotics from each sampling day were used as reference samples to determine treatment differences.

\subsection{Studied genes}

Oligonucleotide primer sequences used to amplify specific gene products are shown in Table 1. Selected genes could be classified into four groups: metabolism, immunity, cell regulation, and cellular stress. To monitor the putative metabolic changes induced by mortality emergence, we characterized expression of four genes involved in ATP synthesis (malate dehydrogenase $(M D H)$, $\mathrm{NADH}$ dehydrogenase subunit $1(\mathrm{NDH}-1)$, cytochrome $\mathrm{C} 1(\mathrm{CC}-1)$ and ATP synthase f0 subunit6 $(A S-6)$ ), two genes of lipids metabolism (endothelial lipase (EDL) and delta9 desaturase (D9-des) and two of protein synthesis (glutamine synthetase (GS) and translation initiator factor elF-2B delta subunit (elF-2b)).

To investigate immune response and cell regulation, six genes (cathepsin $B(C T B)$, annexin $(A N X)$, natural killer receptor $(N K-r e c)$, killer cell lectin-like receptor (KC-rec), MYC-homolog $(M Y C-h)$ and RAS suppressor (SUP)) was selected from previous EST collections. Finally, cellular stress was investigated through expression of genes involved in antioxidant defense (peroxideroxin $6(P R D X 6)$ ), cytoprotection (heat shock protein $70($ HSP70) and pernine $(P R N)$ ) and xenobiotic detoxification (cytochrome P 450 (CP450)).

\subsection{Statistical analysis}

Analyses were carried out using Software $S A S \otimes$ system (8.2). The significance value for all analyses was set at $p<0.05$. PROC GLM (one-way ANOVA) was used to compare relative gene expression between treatments at each sampling days and to show ontogenetic effects on each treatment. Where differences were detected, LSMEANS (t-test) multiple comparisons tests were used to determine which means were significantly different. Residuals were graphically assessed for normality using the PROC PLOT function coupled with univariate procedure (PROC 
UNIVARIATE). Homogeneity was tested using the O'brien test. When normality precept was not realized, LOG transformation was used. Linear regressions were carried out using Sigma plot 8.0 (SYSTAT Software Inc, USA). Data were presented with mean \pm standard deviation.

\section{Results}

RT-PCR was performed with RNA isolated from larvae of 6 to $20 \mathrm{dpf}$; transcripts were detected in all larval stages. Transcript levels were compared between treatments at each sampling day (using the antibiotic treatment as a reference sample), led us to classify the 18 genes into six groups of response (Figure 1). In the first group, which included $M D H, C P 450, D 9-$ des, and NK-rec, no significant differences were found between treatments. NDH-1, CC1, AS-6, and EDL constituted the second group and were characterized by a significantly lower gene expression in untreated larvae at $20 \mathrm{dpf}$, when massive mortality occurred. The third group included the two genes involved in protein synthesis (GS and elF-2B); it showed over-expression at 6 and $13 \mathrm{dpf}$ and under-expression when mortality occurred in the untreated larvae. The fourth group, PRN, HSP70, and MYC-h, had significantly higher expression levels at $13 \mathrm{dpf}$ and significantly lower levels at $20 \mathrm{dpf}$ in untreated larvae. PRDX6 and KC-rec showed a similar pattern except at $20 \mathrm{dpf}$, when no significant difference was found. ANX and SUP composed the last group, in which we measured significantly higher expression levels between 13 and $20 \mathrm{dpf}$ in untreated larvae. Finally, the unclassified CTB was characterized by a higher transcript level at 6 $\mathrm{dpf}$, a similar level at $13 \mathrm{dpf}$, and a lower level at $20 \mathrm{dpf}$ in untreated larvae.

\section{Discussion}

\subsection{Mortality emergence and variation of gene expression}

In the present study, we report, for the first time, molecular and physiological responses of oyster larvae during massive mortality process, particularly at the metabolism, immunity, cellular stress and cell regulation levels. Due to the microscopic size of pelagic larvae, the study of immunity at cellular level is very difficult, but we showed that the use of relative gene expression regulation is a powerful tool. As the transcript level is equilibrium between production and degradation, it is indeed not possible to translate directly to cellular activity, but observed changes of gene expression can be related to their putative functions. The emergence of massive mortality was characterized by a decrease of relative gene expression of 15 out of 18 genes in moribund larvae (untreated larvae that showed subsequent mortality at $20 \mathrm{dpf}$ ). Beside this downregulation, we measured that, comparatively to antibiotic control, 9 genes was up-regulated at 13 $\mathrm{dpf}$, suggesting that gene regulation began one week before mortality emergence and depended to the infection intensity. Recently, the impact of infection intensity on gene regulation was demonstrated in adults of $C$. virginica challenged by $P$. marinus (Wang et al. 2010). Similarly, Chaney and Gracey (2011) found up-regulated genes associated to massive mortality emergence from haemolymph of $C$. gigas.

\subsection{Genes related to metabolism}

For genes related to energy metabolism, moribund larvae at $20 \mathrm{dpf}$ had lower transcript abundances of $\mathrm{NDH}-1, C \mathrm{C}-1$, and $A S-6$. The NADH dehydrogenase subunit $1(\mathrm{NDH}-1)$, cytochrome $\mathrm{c} 1$ (CC-1), and ATP synthase f0 subunit 6 (AS-6) genes code for protein subunits of electron chain transport complex I, III, and V, respectively. Interestingly, as described in Genard et al. (2011), we observed a decline in the activities of two enzymes involved in energy production (citrate synthase and cytochrome oxidase) along with these other molecular changes in moribund larvae, illustrating the correspondence between the molecular and physiological energy response to mortality emergence. As discussed previously in the companion paper (Genard et al. 2011), the decreased metabolic activity could be associated with a metabolic depression explained by a lack of energy substrate (principally lipids and proteins) due to limited feeding and a higher energy demand resulting from the immune process activation. To our knowledge, little information 
is yet available on the regulation of genes related to energy metabolism as a function of feeding activity in bivalves (Bacca et al. 2005). Salem et al. (2007) demonstrated that genes from complex III (Ubiquinol-cytochrome c oxidoreductases), complex IV (Cytochrome c oxidase), and complex V (ATP synthase) were down-regulated in starved rainbow trout.

The metabolic depression associated with mortality emergence could also be suggested by the down regulation of two genes related to protein metabolism (GS and elF-2B). Glutamine synthetase (GS) is a ubiquitous enzyme involved in complex cellular functions, including nitrogen metabolism, ammonia detoxification, and the conversion of glutamate to glutamine. In C. gigas, Tanguy et al. (2005) suggested that glutamine produced by glutamine synthetase is required in the formation of amino acids, purines, and pyrimidines, all of which are essential for protein synthesis during oogenesis and embryogenesis. Previous studies on Drosophila melanogaster showed that the loss of glutamine could depress both protein and DNA synthesis and lead to a variety of mitotic defects in this embryonic system (Frenz and Glover, 1996). Translational initiation factor 2 (elF2) is a multifunctional heterotrimeric $\mathrm{G}$ protein which plays a crucial role in the regulation of the initiation step of protein synthesis (Proud, 2005; Suragani et al. 2006). Thus, the low GS and elF-2B transcript abundances measured in moribund larvae could reflect a decrease in protein synthesis; this has been observed in marine snails when temperatures approach lethal levels (Tomanek and Somero, 1999). This hypothesis is supported by our biochemical results: we observed that moribund larvae stopped protein accumulation (Genard et al. 2011).

The impact of massive mortality on lipid metabolism was illustrated by the lower transcript abundance of endothelial lipase (EDL) in moribund larvae. EDL is a phospholipase which has a high affinity for high-density lipoprotein (HDL) phospholipids (Hirata et al. 2000; Ishida et al. 2003). In addition, it has been demonstrated that EDL efficiently cleaves saturated as well as unsaturated fatty acids from HDL phospholipids, making them available for incorporation into endogenous lipids (Strauss et al. 2003; Gauster et al. 2005; Kratky et al. 2005). To our knowledge, no studies have been done on the function of EDL in bivalves. Nevertheless, the presence and importance of $\mathrm{HDL}$ have been demonstrated in molluscs, bivalves, and crustaceans (Dreon et al. 2002; Heras and Pollero, 2002; Walker et al. 2003), suggesting that EDL could play a significant function in fatty acid remodelling and lipid synthesis. Interestingly, we observed a good correspondence between EDL expression and phospholipid content, which was reported in the companion paper (Genard et al. 2011), suggesting a putative role of EDL in phospholipid accumulation in bivalves.

\subsection{Cellular stress and immunity}

As discussed in the companion paper (Genard et al. 2011), the higher activity levels of superoxide dismutase (SOD) and gluthatione peroxidase (GPX) in untreated larvae at $13 \mathrm{dpf}$ led us to suggest an activation of antioxidant defences before the mass mortality event. We had hypothesized that the increased antioxidant activity was induced to manage reactive oxygen species (ROS) that can be accumulated during an immune response, thus avoiding oxidative damage to the cell. In untreated larvae, the antioxidant defence activation at $13 \mathrm{dpf}$ was confirmed by the higher transcript abundance of peroxiredoxin 6 (PRDX6), a key antioxidant enzyme that protects the cells from the damaging action of $\mathrm{H}_{2} \mathrm{O}_{2}$ (Shuvaeva et al. 2009). Recently, the activation of genes associated to PRDX6 in particular and to antioxidant processes in general was observed in C. virginica after $P$. marinus infection (Wang et al. 2010).

Simultaneous with the higher PRDX6 transcript level, we found an over-expression at $13 \mathrm{dpf}$ of two other genes involved in cellular stress: Heat Shock Protein 70 (HSP70) and Pernin (PRN). HSP70 is a stress-response protein implicated in cytoprotection that acts as a molecular chaperone, preventing premature folding of proteins and aiding in the translocation to organelles. Increased levels of HSP70 in various tissues were observed in fish species exposed to bacterial pathogens (Ackerman and Iwana, 2001; Deane et al. 2004). In bivalves, studies showed that the expression of HSP70 increased in C. virginica haemocytes with increasing intensities of Perkinsus infection (Brown et al. 1993); similar observations were made for HSP70 RNA 
transcripts in the haemocytes of scallops infected by Vibrio anguillarum (Song et al. 2006). Pernin, also called cavortin and first discovered in the mussel Perna viridis (Scotti et al. 2001), is a glycosylated protein possessing sequences clearly homologous to the active-site domain of $\mathrm{Cu}-\mathrm{Zn}$ SODs (superoxide dismutases) which acts both as an iron chelator and as a serine protease inhibitor. and (Scotti et al. 2001). Pernin has the capacity to inhibit in vitro P. marinus growth (Gauthier and Vasta, 1994). Tanguy et al. (2004) identified a gene coding for a Pernin among $C$. virginica haemocytes and observed an increase of mRNA expression after 45 days of $P$. marinus exposure, suggesting the possible involvement of Pernin in the response to parasite infection. Moreover, Huvet et al. (2004) suggested that cavortin (or pernin) can act in cellular host protection against the reactive oxygen intermediate (ROI) in C. gigas infected by Vibrio splendidus. The properties of HSP70 and Pernin indicate that these proteins could play similar functions in cytoprotection and immunity. As for PRDX6, we can hypothesize that the overexpression at $13 \mathrm{dpf}$ in untreated larvae enhances cells protection against reactive oxygen species or intermediates (ROS or ROI) produced during the immune response. Inversely, the down-expression at $20 \mathrm{dpf}$ could indicate a decline of cytoprotective abilities as supported by the higher lipids peroxidation level observed in moribund larvae.

In untreated larvae, the evolution of MYC homologue (MYC-h) transcript abundance was significantly correlated with the expression profiles of $H S P 70$ and PRN, suggesting that MYC-h expression was similarly regulated when mortality event occurred. MYC-h belongs to the protooncogene family and is involved in the control of metabolism, protein biosynthesis, cell cycle regulation, cell adhesion, and the cytoskeleton (Dang et al. 2006); it is also able to elicit the adverse process programmed cell death (Evan et al. 1992; Nilsson et al. 2003). In C. gigas, the MYC homologue appeared to be up-regulated after 21 days of hydrocarbon exposure (Boutet et al. 2004) and under hypoxic conditions (David et al. 2005). According to these authors, MYC-h over-expression could enhance cell protection. In this context, like HSP70 and PRN, the overexpression at $13 \mathrm{dpf}$ could be linked to increased cell protection, while the down-expression at 20 $\mathrm{dpf}$ reflected the decrease of cytoprotective abilities in moribund larvae.

Activation of the immune response can be seen in the over-expression at $13 \mathrm{dpf}$ of one gene linked to pathogen recognition and killer cell regulation: killer cell lectin-like receptor $(K C-r e c)$. This gene was similar to various C-type lectin receptors (Jenny et al. 2002). Lectins are specialized proteins that have the ability to recognize specific pathogen-associated carbohydrate structures and cause agglutination of cells, promote cellular adhesion, and mediate the innate immune response (Geijtenbeek et al. 2004; McGreal et al. 2004; Allam et al. 2006; Yamaura et al. 2008). Recently, the activation of C-type lectin related genes was found after $P$. Marinus infection in adults of C. virginica (Wang et al. 2010).

The presence of an immune response could also be suggested by the level of cathepsin $B$ (CTB) transcript in untreated larvae at $6 \mathrm{dpf}$. Cathepsin are lysosomal cysteine proteinases involved in intracellular protein degradation and in the regulation of melanization (Soderhall et al. 1998; Kanost, 1999; Iwanaga and Lee, 2005). EST of cathepsins were identified in C. virginica (embryo and haemocytes) by Jenny et al. (2002), in the haemocytes of bacterial-challenged $C$. gigas (Gueguen et al. 2003) or before mass mortality occurrence in the same specie (Chaney and Gracey, 2011). In regard to these cathepsin properties, the high transcript abundance measured at $6 \mathrm{dpf}$ in untreated larvae could be linked to high protein degradation induced in the first moments of the immune response while the decline at $20 \mathrm{dpf}$ could be related to the degradation of immune abilities.

Annexin (ANX) and RAS suppressor (SUP) also showed an over-expression at 13 and $20 \mathrm{dpf}$ that could be associated with the activation of immune response. The annexins have diverse functions in cellular activities that include vesicle trafficking, cell division, apoptosis, inflammatory response, calcium signalling, and growth regulation. ANX acts as a secondary mediator of antiinflammatory glucocorticoids (Perretti et al. 2008) and has been identified as one of the "eat-me" signals that allows apoptotic cells to be recognized and ingested by phagocytes (Parente and Solito, 2004; Perretti et al. 2004). RAS suppressor (SUP) is a member of RAS effectors thought to regulate cell proliferation and apoptosis involved in tumor regulation (Agathanggelou et al. 2005; Kumari et al. 2009). RAS associated genes were known to be involved Neoplasia in M. 
trossulus (Ciocan et al. 2006), suggesting a putative function during pathology. While little is known about ANX and SUP functions in oyster larvae, the over-expression of these two genes at 13 and $20 \mathrm{dpf}$ (the only ones) in moribund larvae indicate that both played an important function during pathogenic infection, probably to manage the inflammatory response and the apoptotic process as suggested in adult oysters during $P$. marinus infection in C. virginica (Wang et al. 2010) or before mass mortality in C. gigas (Chaney and Gracey, 2011).

\section{Conclusion}

To our knowledge, this study is the first to report the molecular and physiological processes of bivalve larvae reared in contrasting microbial environments where massive mortality occurred. Comparisons of biochemical and physiological results provided additional evidence supporting previous suppositions, such as the metabolic depression in moribund larvae and the activation of immune response and antioxidant defences before the appearance of massive mortality. Moreover, our results illustrated the importance of cytoprotection processes, inflammatory response management, and cell regulation during a massive mortality event.

\section{Acknowledgments}

The authors are grateful to IRZC staff for oyster production. Thanks are addressed to Laure Devine for linguistic revision. This study was supported by grants from the Natural Sciences and Engineering Research Council of Canada and the Réseau Aquacole du Québec to F.P. and R.T.

\section{References}

Ackerman, P.A., Iwama, G.K., 2001. Physiological and cellular stress responses of juvenile rainbow trout to vibriosis. J. Aquat. Anim. Health 13, 173-180.

Agathanggelou A., Cooper W. N., Latif F., 2005. Role of the ras-association domain family 1 tumor suppressor gene in human cancers. Cancer Res. 65, 3497-3508.

Allam, B., Paillard, C., Auffret, M., Ford, S.E., 2006. Effects of the pathogenic Vibrio tapetis on defence factors of susceptible and non-susceptible bivalve species: II. Cellular and biochemical changes following in vivo challenge. Fish Shellfish Immunol. 20, 384-397.

Bacca, H., Huvet, A., Fabioux, C., Daniel, J.Y., Delaporte, A., Pouvreau, S., Van Wormhoudt, A., Moal, J., 2005. Molecular cloning and seasonal expression of oyster glycogen phosphorylase and glycogen synthase genes. Comp. Biochem. Physiol. B. 140, 635-646.

Barnathan, G., 2009. Non-methylene-interrupted fatty acids from marine invertebrates: Occurrence, characterization and biological properties. Biochimie 91, 671-678.

Boutet, I., Tanguy, A., Moraga, D., 2004. Response of the Pacific oyster Crassostrea gigas to hydrocarbon contamination under experimental conditions. Gene 329, 147-157.

Brown, D.C., Bradley, B.P., Paynter, K.T., 1993. The physiological effects of protozoan parasitism on the eastern oyster, Crassostrea virginica: Induction of stress proteins. J. Shellfish. Res. 12, 135-136.

Ciocan C. M., Moore J. D., Rotchell J. M., 2006. The role of ras gene in the development of haemic neoplasia in Mytilus trossulus. Mar. Environ. Res. 62, S147-S150.

Chaney, M.L., Gracey, A.Y., 2011. Mass mortality in Pacific oysters is associated with a specific gene expression signature. Mol. Ecol. 20, 2942-2954. 
Collin, H., Meistertzheim, A.L., David, E., Moraga, D., Boutet, I., 2010. Response of the Pacific oyster Crassostrea gigas, Thunberg 1793, to pesticide exposure under experimental conditions. J. Exp. Biol. 213, 4010-4017.

Dang, C.V., O'Donnell, K.A., Zeller, K.I., Nguyen, T., Osthus, R.C., Li, F., 2006. The c-Myc target gene network. Semin. Cancer Biol. 16, 253-264.

David, E., Tanguy, A., Pichavant, K., Moraga, D., 2005. Response of the Pacific oyster Crassostrea gigas to hypoxia exposure under experimental conditions. F. Journal 272, 56355652.

Deane, E.E., Li, J., Woo, Y.S., 2004. Modulated heat shock protein expression during pathogenic Vibrio alginolyticus stress of sea bream. Dis. Aquat. Org. 62, 205-215.

Dreon, M., Lavarias, S., Garin, C.F., Heras, H., Pollero, R.J., 2002. Synthesis, distribution, and levels of an egg lipoprotein from the apple snail Pomacea canaliculata (Mollusca : Gastropoda). J. Exp. Zool. 292, 323-330.

Evan, G.I., Wyllie, A.H., Gilbert, C.S., Littlewood, T.D., Land, H., Brooks, M., Waters, C.M., Penn, L.Z., Hancock, D.C., 1992. Induction Of Apoptosis In Fibroblasts By C-Myc Protein. Cell $69,119-128$.

Fleury, E., Huvet, A., Lelong, C., de Lorgeril, J., Boulo, V., Gueguen, Y., Bachere, E., Tanguy, A., Moraga, D., Fabioux, C., Lindeque, P., Shaw, J., Reinhardt, R., Prunet, P., Davey, G., Lapegue, S., Sauvage, C., Corporeau, C., Moal, J., Gavory, F., Wincker, P., Moreews, F., Klopp, C., Mathieu, M., Boudry, P., Favrel, P., 2009. Generation and analysis of a 29,745 unique Expressed Sequence Tags from the Pacific oyster (Crassostrea gigas) assembled into a publicly accessible database: the GigasDatabase. BMC Genomics 10, 341-355.

Frenz, L.M., Glover, D.M., 1996. A maternal requirement for glutamine synthetase I for the mitotic cycles of syncytial Drosophila embryos. J. Cell Sci. 109, 2649-2660.

Gauster, M., Rechberger, G., Sovic, A., Horl, G., Steyrer, E., Sattler, W., Frank, S., 2005. Endothelial lipase releases saturated and unsaturated fatty acids of high density lipoprotein phosphatidylcholine. J. Lipid Res. 46, 1517-1525.

Gauthier, J.D., Vasta, G.R., 1994. Inhibition Of In-Vitro Replication Of The Oyster Parasite Perkinsus-Marinus By The Natural Iron Chelators Transferrin, Lactoferrin, And Desferrioxamine. Dev. Comp. Immunol. 18, 277-286.

Geijtenbeek, T.B.H., van Vliet, S.J., Engering, A., t Hart, B.A., van Kooyk, Y., 2004. Self- and nonself-recognition by C-type lectins on dendritic cells. Annu. Rev. Immunol. 22, 33-54.

Genard, B., Pernet, F., Lemarchand, K., Boudry, P., Moraga, D., Tremblay, R., 2011. Physiological and biochemical changes during premetamorphic development in American oyster Crassostrea virginica in relation to mortality emergence. Aquat. Living Resour. 24, 247-260.

Gueguen, Y., Cadoret, J.P., Flament, D., Barreau-Roumiguiere, C., Girardot, A.L., Garnier, J., Hoareau, A., Bachere, E., Escoubas, J.M., 2003. Immune gene discovery by expressed sequence tags generated from hemocytes of the bacteria-challenged oyster, Crassostrea gigas. Gene 303, 139-145.

Heras, H., Pollero, R.J., 2002. Lipoproteins from plasma and perivelline fluid of the apple snail Pomacea canaliculata. Biocell 26, 111-118.

Hirata, K., Ishida, T., Matsushita, H., Tsao, P.S., Quertermous, T., 2000. Regulated expression of endothelial cell-derived lipase. Biochem. Biophys. Res. Commun. 272, 90-93.

Huvet, A., Herpin, A., Degremont, L., Labreuche, Y., Samain, J.F., Cunningham, C., 2004. The identification of genes from the oyster Crassostrea gigas that are differentially expressed in progeny exhibiting opposed susceptibility to summer mortality. Gene 343, 211-220. 
Ishida, T., Hirata, K., Kojima, Y., Choi, S., Cooper, A., Quertermous, T., Yokoyama, M., 2003. Altered expression of endothelial cell-derived lipase in diseased vessel wall and its impact on HDL metabolism. Atheroscler. Suppl. 4, 232-233.

Iwanaga, S., Lee, B.L., 2005. Recent advances in the innate immunity of invertebrate animals. J. Biochem. Mol. Biol. 38, 128-150.

Jenny, M.J., Chapman, R.W., Mancia, A., Chen, Y.A., McKillen, D.J., Trent, H., Lang, P., Escoubas, J.M., Bachere, E., Boulo, V., Liu, Z.J., Gross, P.S., Cunningham, C., Cupit, P.M., Tanguy, A., Guo, X., Moraga, D., Boutet, I., Huvet, A., De Guise, S., Almeida, J.S., Warr, G.W., 2007. A cDNA Microarray for Crassostrea virginica and C. gigas. Mar. Biotechnol. 9, 577-591.

Jenny, M.J., Ringwood, A.H., Lacy, E.R., Lewitus, A.J., Kempton, J.W., Gross, P.S., Warr, G.W., Chapman, R.W., 2002. Potential indicators of stress response identified by expressed sequence tag analysis of hemocytes and embryos from the American oyster, Crassostrea virginica. Mar. Biotechnol. 4, 81-93.

Kanost, M.R., 1999. Serine proteinase inhibitors in arthropod immunity. Dev. Comp. Immunol. 23, 291-301.

Kratky, D., Zimmermann, R., Wagner, E.M., Strauss, J.G., Jin, W.J., Kostner, G.M., Haernmerle, G., Rader, D.J., Zechner, R., 2005. Endothelial lipase provides an alternative pathway for FFA uptake in lipoprotein lipase-deficient mouse adipose tissue. J. Clin. Invest. 115, 161-167.

Kumari G., Mahalingam S., 2009. Extracellular signal-regulated kinase 2 (ERK-2) mediated phosphorylation regulates nucleo-cytoplasmic shuttling and cell growth control of Ras-associated tumor suppressor protein, RASSF2. Exp. Cell Res. 315, 2775-2790.

Livak, K.J., Schmittgen, T.D., 2001. Analysis of relative gene expression data using real-time quantitative PCR and the 2(T)(-Delta Delta C) method. Methods 25, 402-408.

McGreal, E.P., Martinez-Pomares, L., Gordon, S., 2004. Divergent roles for C-type lectins expressed by cells of the innate immune system. Mol. Immunol. 41, 1109-1121.

Nilsson, J.A., Cleveland, J.L., 2003. Myc pathways provoking cell suicide and cancer. Oncogene 22, 9007-9021.

Olafsen, J.A., 2001. Interactions between fish larvae and bacteria in marine aquaculture. Aquaculture 200, 223.

Paillard, C., Le Roux, F., Borrego, J.J., 2004. Bacterial disease in marine bivalves, a review of recent studies: Trends and evolution. Aquat. Living Resour. 17, 477-498.

Parente, L., Solito, E., 2004. Annexin 1: more than an anti-phospholipase protein. Inflamm. Res. 53, 125-132.

Perretti, M., Flower, R.J., 2008. Anti-inflammatory glucocorticoids and annexin 1, in: Rossi, A.G, Sawatzky, D.A., (Eds),. The Resolution of Inflammation. Birkhäuser Verlag Basel, Switzerland, pp 141-158.

Perretti, M., Solito, E., 2004. Annexin 1 and neutrophil apoptosis. Biochem. Soc. Trans. 32, 507-510.

Pfaffl, M.W., 2001. A new mathematical model for relative quantification in real-time RT-PCR. Nucleic Acids Res. 29.

Proud, C.G., 2005. elF2 and the control of cell physiology. Semin. Cell Dev. Biol. 16, 3-12.

Quilang, J., Wang, S.L., Li, P., Abernathy, J., Peatman, E., Wang, Y.P., Wang, L.L., Shi, Y.H., Wallace, R., Guo, X.M., Liu, Z.J., 2007. Generation and analysis of ESTs from the eastern oyster, Crassostrea virginica Gmelin and identification of microsatellite and SNP markers. Bmc Genomics 8, 157-167. 
Salem, M., Silverstein, J., lii, C.E.R., Yao, J., 2007. Effect of starvation on global gene expression and proteolysis in rainbow trout (Oncorhynchus mykiss). Bmc Genomics 8, 328-343.

Samain, J.F., Dégremont, L., Soletchnik, P., Haure, J., Bédier, E., Ropert, M., Moal, J., Huvet, A., Bacca, H., Van Wormhoudt, H., Delaporte, M., Costil, K., Pouvreau, S., Lambert, S., Boulo, V., Soudant, P., Nicolas, J.L., Le Roux, F., Renault, T., Gagnaire, B., Gereth, F., Boutet, I., Burgeot, T., Boudry, P., 2007. Genetically based resistance to summer mortality in the Pacific oyster (Crassostrea gigas) and its relationship with physiological, immunological characteristics and infection processes. Aquaculture 268, 227-243.

Scotti, P.D., Dearing, S.C., Greenwood, D.R., Newcomb, R.D., 2001. Pernin: a novel, selfaggregating haemolymph protein from the New Zealand green-lipped mussel, Perna canaliculus (Bivalvia : Mytilidae). Comp. Biochem. Physiol. B. 128, 767-779.

Shuvaeva, T.M., Novoselov, V.I., Fesenko, E.E., Lipkin, V.M., 2009. Peroxiredoxins, a new family of antioxidant proteins. Russ. J. Bioorg. Chem. 35, 523-537.

Soderhall, K., Cerenius, L., 1998. Role of the prophenoloxidase-activating system in invertebrate immunity. Curr. Opin. Immunol. 10, 23-28.

Song, L.S., Wu, L.T., Ni, D.J., Chang, Y.Q., Xu, W., Xing, K.Z., 2006. The cDNA cloning and mRNA expression of heat shock protein 70 gene in the haemocytes of bay scallop (Argopecten irradians, Lamarck 1819) responding to bacteria challenge and naphthalin stress. Fish Shellfish Immunol. 21, 335-345.

Strauss, J.G., Hayn, M., Zechner, R., Levak-Frank, S., Frank, S., 2003. Fatty acids liberated from high-density lipoprotein phospholipids by endothelial-derived lipase are incorporated into lipids in HepG2 cells. Biochem. J. 371, 981-988.

Suragani, R., Ghosh, S., Ehtesham, N.Z., Ramaiah, K.V.A., 2006. Expression and purification of the subunits of human translational initiation factor 2 (elF2): Phosphorylation of elF2 alpha and beta. Protein Express. Purif. 47, 225-233.

Sussarellu, R., Fabioux, C., Le Moullac, G., Fleury, E., Moraga, D., 2010. Transcriptomic response of the Pacific oyster Crassostrea gigas to hypoxia. Mar. Genom. 3, 133-143.

Tanguy, A., Bierne, N., Saavedra, C., Pina, B., Bachere, E., Kube, M., Bazin, E., Bonhomme, F., Boudry, P., Boulo, V., Boutet, I., Cancela, L., Dossat, C., Favrel, P., Huvet, A., Jarque, S., Jollivet, D., Klages, S., Lapegue, S., Leite, R., Moal, J., Moraga, D., Reinhardt, R., Samain, J.F., Zouros, E., Canario, A., 2008. Increasing genomic information in bivalves through new EST collections in four species: Development of new genetic markers for environmental studies and genome evolution. Gene 408, 27-36. 272, 390-403.

Tanguy, A., Boutet, I., Moraga, D., 2005. Molecular characterization of the glutamine synthetase gene in the Pacific oyster Crassostrea gigas: expression study in response to xenobiotic exposure and developmental stage. Biochim. Biophys. Acta-Gene Struct. Expression $1681,116-125$

Tanguy, A., Guo, X.M., Ford, S.E., 2004. Discovery of genes expressed in response to Perkinsus marinus challenge in Eastern (Crassostrea virginica) and Pacific (C-gigas) oysters. Gene 338, 121-131.

Tirape, A., Bacque, C., Brizard, R., Vandenbulcke, F., Boulo, V., 2007. Expression of immunerelated genes in the oyster Crassostrea gigas during ontogenesis. Dev. Comp. Immunol. 31, 859873.

Tomanek, L., Somero, G.N., 1999. Evolutionary and acclimation-induced variation in the heatshock responses of congeneric marine snails (genus Tegula) from different thermal habitats: Implications for limits of thermotolerance and biogeography. J. Exp. Biol. 202, 2925-2936.

Tikunov, A. P., Johnson, C. B., Lee, H., Stoskopf, M. K., Macdonald, J. M., 2010. Meatbolomic investigations of American oysters using 1H-NMR Spectroscopy. Mar. Drugs 8, 2578 - 2596. 
Travers, M.A., Meistertzheim, A.L., Cardinaud, M., Friedman, C.S., Huchette, S., Moraga, D., Paillard, C., 2010. Gene expression patterns of abalone, Haliotis tuberculata, during successive infections by the pathogen Vibrio harveyi. J. Invertebr. Pathol. 105, 289-297.

Wang, S.L., Peatman, E., Liu, H., Bushek, D., Ford, S.E., Kucuktas, H., Quilang, J., Li, P., Wallace, R., Wang, Y.P., Guo, X.M., Liu, Z.J., 2010. Microarray analysis of gene expression in eastern oyster (Crassostrea virginica) reveals a novel combination of antimicrobial and oxidative stress host responses after dermo (Perkinsus marinus) challenge. Fish Shellfish Immunol. 29, 921-929.

Walker, A., Ando, S., Lee, R.F., 2003. Synthesis of a high-density lipoprotein in the developing blue crab (Callinectes sapidus). Biol. Bull. 204, 50-56.

Yamaura, K., Takahashi, K.G., Suzuki, T., 2008. Identification and tissue expression analysis of C-type lectin and galectin in the Pacific oyster, Crassostrea gigas. Comp. Biochem. Physiol. B. 149, 168-175.

Zapata, M., Tanguy, A., David, E., Moraga, D., Riquelme, C., 2009. Transcriptomic response of Argopecten purpuratus post-larvae to copper exposure under experimental conditions. Gene 442, 37-46. 
Figure 1. Relative expression of selected genes in Crassostrea virginica larvae untreated with antibiotic. A massive mortality was observed at $20 \mathrm{dpf}$. Relative gene expression data were estimated by comparison with the corresponding level from larvae that had the antibiotic treatment. Data are means \pm SD, * Significant difference $(p<0.05)$, --- reference level (antibiotic); see Table 1 for gene abbreviations.

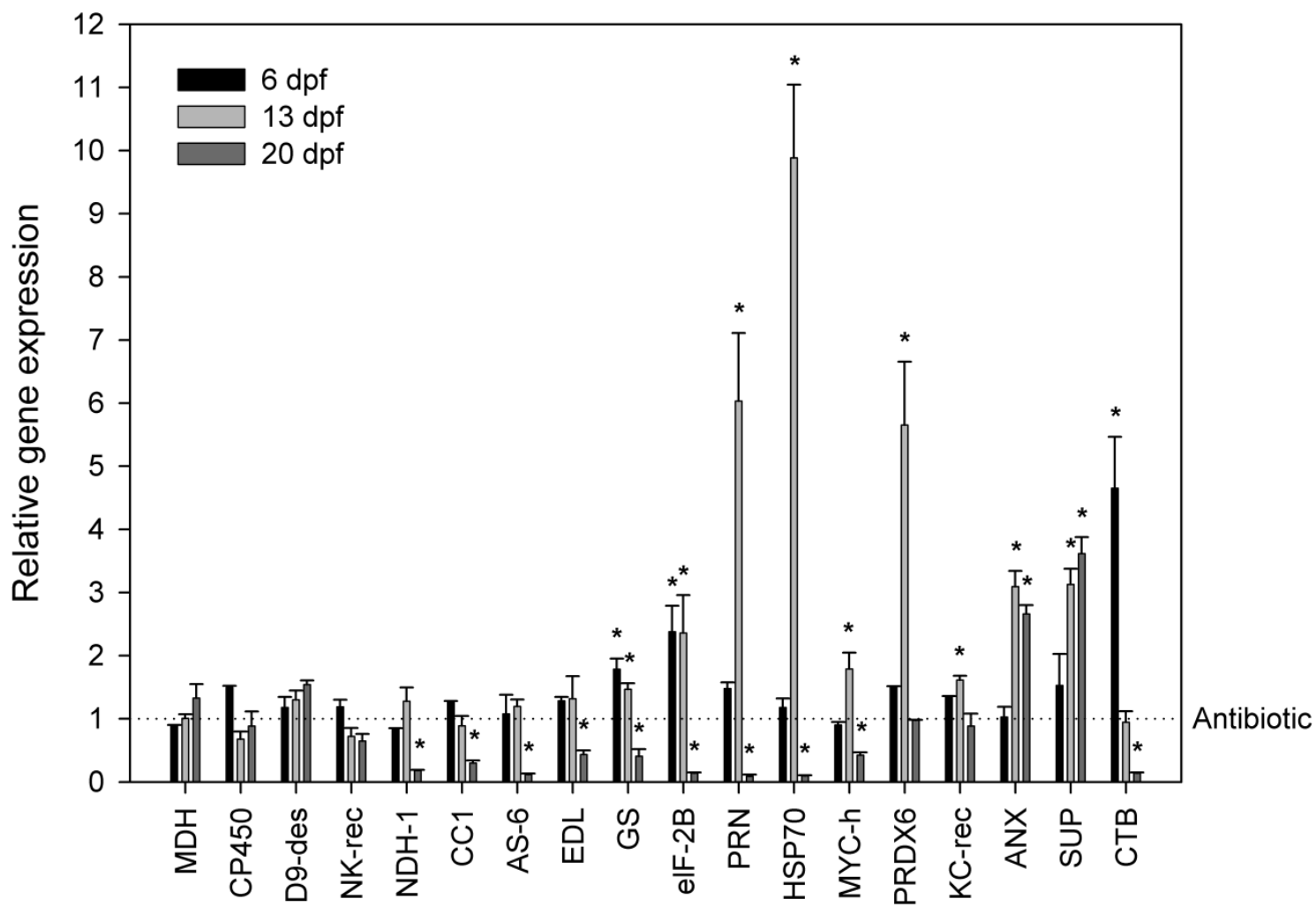


Table 1. Details of genes and primers used in the quantitative real-time PCR relative expression analysis.

\begin{tabular}{|c|c|c|c|c|c|}
\hline Genes & Label & $\begin{array}{l}\text { GEN BANK } \\
\text { ref. } \\
\end{array}$ & Function & Forward primer (5'-3') & Reverse primer (5'-3') \\
\hline Ribosomial protein $18 \mathrm{~s}$ & R18s & CX069129 & Putative housekeeping gene & GTCTGGTTAATTCCGATAACGAACGGAACTCTA & TGCTCAATCTCGTGTGGCTAAACGCAACTTG \\
\hline Malate dehydrogenase precursor & MDH & BG624325 & Energy metabolism (acid citric cycle) & ACTGAAGTTGTGGAGGCTAAGGCT & ATTCCTAGATTTTTCTCCACACC \\
\hline NADH dehydrogenase subunit 1 & NDH-1 & CD648997 & Energy metabolism (electron chain transport complex I) & TCGCGCGCTGCTTTCCCACGGTT & TTACCGCACCAAGAGCTACGCAGC \\
\hline Cytochrome C1 & CC-1 & CD526711 & Energy metabolism (electron chain transport complex III) & СTTGCTCTTTTTTTCAGACACATAGA & GCATTCATCCAGACAGGTAGTCCTTATGAG \\
\hline ATP synthase f0 subunit 6 & AS-6 & EE677700 & Energy metabolism (electron chain transport complex V) & ATGCCAAGCATGTTCTACAGAGT & GCAAAGGATCGCTCCTACCAAAGC \\
\hline Delta9 desaturase & D9-des & CX069227 & Lipid metabolism (fatty acid desaturation) & TACTGTCTTCTGCTAAACGCCAC & GTCGTGATATTGAGGTGCCAGCC \\
\hline Endothelial lipase precursor & EDL & CD647348 & Lipid metabolism (phospholipase) & GCCCACACCATGGGATACGCCGG & TGGCACCCCGGTTGTCTCGTCCC \\
\hline Glutamine synthetase & GS & CG1753 & Protein metabolism (amino acid synthesis) & ACGGAGGTTGACGGGACTT & GCTGGCACCACGATTGG \\
\hline Translation initiation factor eIF-2B delta subunit & eIF-2B & EE677861 & Protein synthesis regulation (DNA translation) & GGCTGGTATCCCTTGCTCCTA & CACTTTAGTAGCCTCTTGCATTGC \\
\hline Cathepsin B & СТВ & BG624471 & Proteolysis, pathogen recognition & CCTACTCCATCAAGTCATGTGACCA & ATACCCAGTGTAAGCGCCCTCT \\
\hline NKR-P1B (Natural Killer receptor) & NK-rec & BG624594 & Non-self recognition (lectin receptor family) & GCCTGATTAAGTGTCCCATGATGGTTC & GAGTGTCCCAGTCATGGGCCACACCCA \\
\hline Killer Cell lectin-like receptor & KC-rec & BG624932 & Non-self recognition (lectin receptor family) & GGTCTTTGCCAGTTTCGGGTTTATAAC & TGGTCTGCGGAGACACCAATATGGCCT \\
\hline Annexin & ANX & CD648336 & Apoptose, inflammation response & GATAAGAATCATCGTCACTCGGGCCGA & AАTTTTCACTTAAACACTCCCACATAC \\
\hline Peroxiredoxin 6 & PRDX6 & CX069146 & Oxidative stress (antioxidant enzyme) & GATGACGTCCCCAGTCATGAGGGGTGGTC & TGGGGGATGGAGGGTAAGACCATACACTT \\
\hline Cytochrome P 450 & CP450 & CD526847 & Xenobiotic detoxification & GTGCATCAAAGAATTTTGGATAC & TGCAATAATTTTTGAAGCCCCGG \\
\hline Heat shock protein 70 & HSP70 & CX069205 & Chaperone protein (cytoprotection) & ATGAGTAAACACCAACAGGCCATCGG & AAGATAGTGTTCGTAGGGTTCATGGC \\
\hline Pernin precursor & PRN & CD526735 & Iron chelator (cytoprotection) & СTCCTGATCATGCTGAACCT & GATCATGTTTGTTCGGTCATC \\
\hline RAS suppressor & SUP & BG624647.1 & Cell division inhibitor & ACTGAAGTTGTGGAGGCTAAGGCT & ATTCCTAGATTTTTCTCCACACC \\
\hline MYC-homologe & MYC-h & CX069136 & Cell division, proto-oncogene & TTCTATAACGGAACATTATACCAACAAGG & CAACATTTACCTGGGGCAGGTGGGTTCAG \\
\hline
\end{tabular}

